\title{
Green Roof Substrate Type and Depth Affect the Growth of the Native Species Dianthus fruticosus Under Reduced Irrigation Regimens
}

\author{
Panayiotis A. Nektarios' ${ }^{1}$ Ioannis Amountzias, Iro Kokkinou, \\ and Nikolaos Ntoulas \\ Laboratory of Floriculture and Landscape Architecture, Department of Crop \\ Science, Agricultural University of Athens, 75, Iera Odos, Athens, 118 55, Greece
}

Additional index words. pumice, zeolite, perlite, SPAD, chlorophyll, compost, drought stress

Abstract. Extensive green roofs are a promising technology for reintroducing lost flora in degraded urban environments, but further research is needed for their application in semiarid regions. Therefore, research was undertaken to determine the effects of substrate type and depth and the amount of irrigation during a drought period on the establishment, growth, and physiology of the native species Dianthus fruticosus sub. fruticosus. Treatments included two substrate types [a soilless substrate (Pum ${ }_{50}$ : Per $\left._{20}: C_{20}: Z_{10}\right)$ or a substrate with soil $\left(S_{15}: P_{40}: P_{20}: C_{20}: Z_{5}\right)$, in which $P u m=$ pumice; Per = perlite; $C=$ compost $Z \mathbf{Z}=$ clinoptinolite zeolite; and $S=$ sandy loam soil, mixed in a volumetric proportion indicated by their subscripts], two substrate depths $(7.5 \mathrm{~cm}$ or $15.0 \mathrm{~cm}$ ), and two irrigation regimens during drought $[15 \%$ or $30 \%$ of pan evaporation $\left.\left(\mathbf{E}_{\text {pan }}\right)\right]$. Measurements included substrate characteristics such as particle size distribution, dry and saturated bulk density, water characteristic curves, and in situ determination of substrate moisture during drought stress. Plant growth was determined based on biometric measurements such as growth index (GI) and dry weight and physiological indicators such as SPAD, chlorophyll ${ }_{a+b}$, and carotenoid contents. It was found that substrate moisture during drought was increased in the soil substrate compared with the soilless substrate as a result of its better water retention capacity in low tensions. Dianthus fruticosus sub. fruticosus growth was promoted by the deep substrate $(15 \mathrm{~cm})$ throughout the entire study, whereas substrate type and irrigation during the drought period did not have an effect. Similarly, leaf dry weight was increased in the deeper substrates, whereas shoot and root dry weights were similar in all treatments. SPAD was found to be a more sensitive method than chlorophyll and carotenoid analysis and revealed an interesting sequence of treatment influences on $D$. fruticosus sub. fruticosus physiology that depended on the climatic conditions and stress imposition. More specifically, during establishment, both substrate type and depth affected growth with the soil substrate and deep profiles yielding higher SPAD measurements. Soon after the initiation of drought, the deep profiles had higher SPAD values than the shallow ones, whereas in high-irrigation regimens and, to a less extent, deeper profiles provided increased SPAD values after the middle of drought imposition. Chlorophyll and carotenoid levels reduced during the drought stress period, but very limited differences were detected between treatments. It was concluded that $D$. fruticosus sub. fruticosus is a very promising native plant for use on extensive green roofs in the Mediterranean region, and its growth was better in a substrate depth of $15 \mathrm{~cm}$. However, its growth was sufficient even with a $7.5-\mathrm{cm}$ substrate depth and irrigation of $15 \% \mathrm{E}_{\text {pan }}$.

Green roofs have been established as an environmentally correct action for the improvement of the environment and the quality of life in contemporary cities as a result of

\footnotetext{
Received for publication 11 May 2011. Accepted for publication 14 June 2011.

We thank L. Kambanis S.A. for providing the compost.

The mention of a trademark, proprietary product, or vendor does not imply endorsement by the authors nor does it imply approval to the exclusion of other products that may also be suitable.

This article is a portion of an MSc thesis submitted by I. Amountzias.

${ }^{1}$ To whom reprint requests should be addressed; e-mail pan@aua.gr.
}

their proven environmental and social benefits. Despite their numerous benefits, green roof construction is progressing slowly in countries that do not provide incentives such as tax deductions or grants. To promote green roof establishment in the semiarid Mediterranean regions, solutions must be given, especially for the aged buildings that occupy the majority of the city cores and have limited additional load-bearing capacity on their frames. In such areas, extensive or semiextensive green roofs seem to be the only applicable solution as a result of their low weight and reduced construction and maintenance costs. Extensive or semi-extensive green roofs can improve the aesthetics and, under certain conditions, the microclimate (Dunnett and
Kingsbury, 2010; Getter and Rowe, 2006; Spronken-Smith and Oke, 1998; Takebayashi and Moriyama, 2009); thus, it is very important to investigate the potential of establishing such roofs by answering fundamental questions: 1) what substrate should be used, and at what depth, to minimize the load weight and yet provide sustainable plant growth; 2 ) which plants can provide adequate and sustainable growth on the particular green roof substrates and depths with minimal resources inputs; and 3 ) how much irrigation would be needed under the harsh semiarid climatic conditions of the Mediterranean region to sustain plant growth?

Green roof weight depends primarily on the substrate and secondly on the weight of the plant material (Scrivens, 1990). To create a system with minimal load, the weight of the substrate must be drastically reduced, whereas in extensive green roofs, the plant weight is negligible. This weight reduction could be accomplished both by the use of lightweight materials and by the reduction of substrate depth. However, apart from the weight factor, green roof substrates must fulfill several criteria: maintain adequate moisture for plant growth, facilitate the quick removal of excess water, provide support and anchoring of the plants, provide nutrients, and possess a $\mathrm{pH}$ and electrical conductivity (EC) appropriate for plant growth. Several researchers have evaluated different lightweight materials as green roof substrates (Beattie and Berghage, 2004, Nektarios et al., 2003; Rowe et al., 2006; Thuring et al., 2010). Beattie and Berghage (2004) indicated that a substrate must consist primarily of inorganic materials, whereas large quantities of composted or other organic substances should be avoided as a result of the substrate subsidence that results from their decomposition. Rowe et al. (2006) evaluated the use of heat-expanded shale in the establishment, growth, and survival of Sedum and native wild plants. The researchers evaluated $60 \%, 70 \%, 80 \%, 90 \%$, and $100 \%$ of heatexpanded shale participation in the substrate mix in conjunction with varying proportions of sand, peat, and compost. They concluded that the substrates with higher shale contents resulted in slightly reduced plant growth and lower visual quality characteristics, irrespective of the plant species studied, but moderately high quantities of heat-expanded shale $(80 \%)$ did not have any negative effects on plant growth and reduced the load weight of the structure. Thuring et al. (2010) evaluated the effects of expanded clay and shale amended with spent mushroom compost on the growth and dry weight of five succulent and herbaceous plants. Despite some individual plant responses, they found that plants grew better in expanded clay compared with expanded shale as a result of its better moisture and nutrientholding capacity. This was especially profound during the drought stress periods.

Substrate depth is the second constituent that has a direct effect on green roof weight, construction cost, and plant survival and growth. The influence of varying extensive green roof substrate depth on plant growth has been investigated by several researchers 


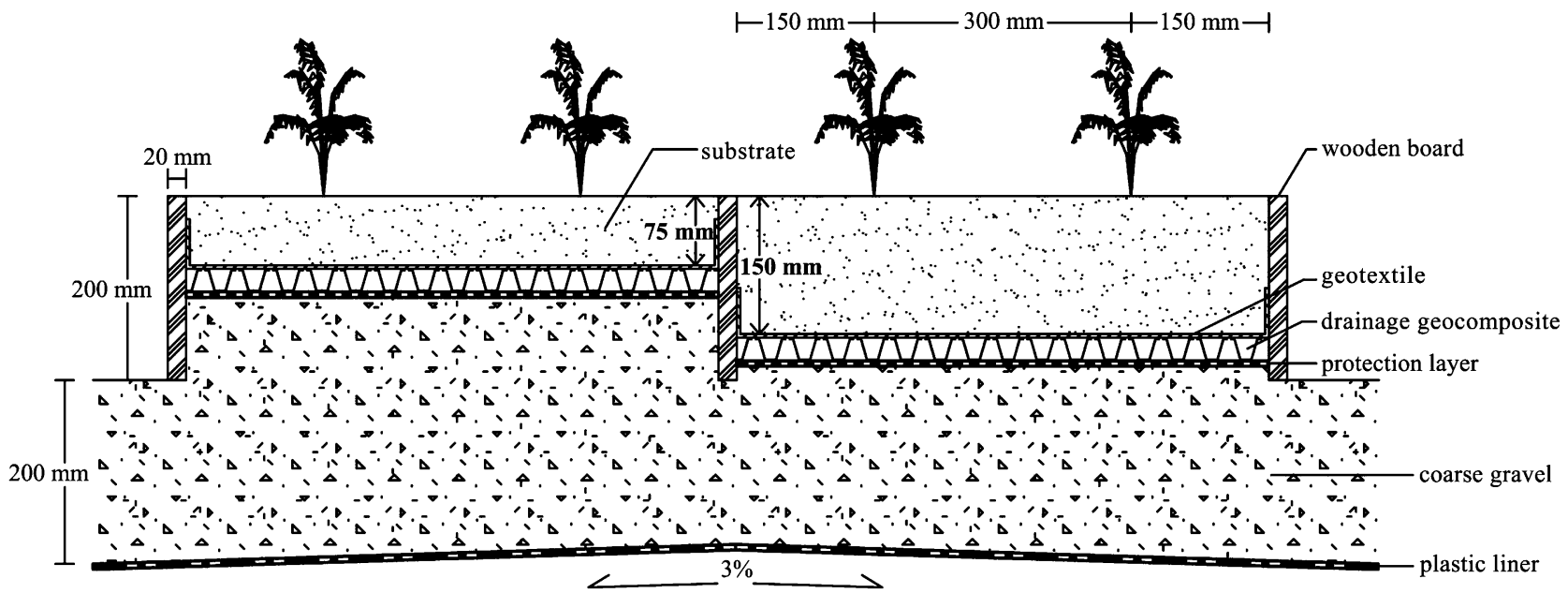

Fig. 1. Construction detail of the experimental plots.

to determine the smallest depth in which plants could grow in an effort to minimize the load to the building structure and the construction cost. The results are consistent because plant growth and survival improve as the depth of the substrate increases (Boivin et al., 2001; Dunnett et al., 2007; Durhman et al., 2007; Getter and Rowe, 2006; Thuring et al., 2010; VanWoert et al., 2005). However, in each case and ecoregion, it is of interest to determine the minimal substrate depth that achieves sufficient sustainability and visual quality of the green roof.

In extensive green roofs, irrigation may compensate for some substrate depth reduction (VanWoert et al., 2005). Although the German green roof specifications (FLL, 2002) have been formulated for northern climates and provide minimal information about green roof irrigation, it has been acknowledged by several researchers that if extensive green roofs are to be installed in semiarid climates, irrigation might be a necessity, especially during the first 1 or 2 years of establishment and during severe drought periods in the summer (Getter and Rowe, 2006; Latocha and Batorska, 2007; Williams et al., 2010; Wolf and Lundholm, 2008). Thuring et al. (2010) found that apart from the irrigation amount, the timing of drought imposition (soon after establishment or later) had also a significant impact on green roof plant establishment, because early drought exhibited adverse effects on plant growth. An additional issue that needs to be addressed concerning the debate about irrigation application on extensive green roofs is that, if they are expected to contribute to the mitigation of urban heat island effect, the green roof plants must transpire as a result of irrigation (Dunnett and Kingsbury, 2010; Spronken-Smith and Oke, 1998).

The final success of an extensive green roof is evaluated by the survival and sustainable growth of the plants. Therefore, the choice of suitable plant material that can withstand the stresses imposed on extensive green roofs under minimal management is of paramount importance. The selection of extensive green roof plant species has been the goal of several research studies with the most successful being the succulent plants, particularly those
Table 1 . Compost analyses in dry samples $\left(105^{\circ} \mathrm{C}\right)$.

\begin{tabular}{|c|c|c|}
\hline Analysis & Value & Method of analysis \\
\hline Organic matter (\%) & 38.70 & A.O.A.C. $967.05 / 16$ th edition \\
\hline $\mathrm{pH}$ in water extract $(3: 50)$ & 8.60 & A.O.A.C. $973.04, \mathrm{I} / 16$ th edition \\
\hline EC in $1: 5$ water extract $\left(\mu \mathrm{S} \cdot \mathrm{cm}^{-1}\right)$ & $5,000.00$ & $\begin{array}{l}\text { Methods of soil analysis, American Society } \\
\text { of Agronomy, No. 9, Part 2, } 1982\end{array}$ \\
\hline $\mathrm{C} / \mathrm{N}$ & 10.70 & \\
\hline Total N (\%) & 2.09 & A.O.A.C. $973.06 / 16$ th edition \\
\hline $\begin{array}{l}\text { Total dissolved } \mathrm{P}_{2} \mathrm{O}_{5} \text { in } \\
\text { inorganic acids }(\%)\end{array}$ & 1.61 & $\begin{array}{l}\text { EC Regulation 2003/2003/3.1.1 and } \\
\text { AFNOR U42-246 }\end{array}$ \\
\hline Total $\mathrm{K}_{2} \mathrm{O}(\%)$ & 2.72 & EC Regulation 2003/2003/3.1.1 and A.A.S. \\
\hline Total MgO (\%) & 1.69 & EC Regulation 2003/2003/8.1 and 8.7 \\
\hline Total Ca $(\%)$ & 7.16 & EC Regulation 2003/2003/8.1 and A.A.S. \\
\hline Total $\mathrm{Na}(\%)$ & 0.31 & EC Regulation $2003 / 2003 / 8.1$ and 8.10 \\
\hline Total Fe $\left(\mathrm{mg} \cdot \mathrm{kg}^{-1}\right)$ & $7,330.00$ & EC Regulation 2003/2003/9.1 and 9.8 \\
\hline Total $\mathrm{Zn}\left(\mathrm{mg} \cdot \mathrm{kg}^{-1}\right)$ & 231.00 & EC Regulation 2003/2003/9.1 and 9.11 \\
\hline Total Mn $\left(\mathrm{mg} \cdot \mathrm{kg}^{-1}\right)$ & 433.00 & EC Regulation 2003/2003/9.1 and 9.9 \\
\hline Total $\mathrm{Cu}\left(\mathrm{mg} \cdot \mathrm{kg}^{-1}\right)$ & 40.00 & EC Regulation 2003/2003/9.1 and 9.7 \\
\hline Total B $\left(\mathrm{mg} \cdot \mathrm{kg}^{-1}\right)$ & 321.00 & EC Regulation $2003 / 2003 / 9.1$ and 9.5 \\
\hline
\end{tabular}

$\mathrm{C} / \mathrm{N}=$ carbon/nitrogen; $\mathrm{Ca}=$ calcium $; \mathrm{Na}=$ sodium; $\mathrm{Fe}=$ iron; $\mathrm{Zn}=$ zinc; $\mathrm{Mn}=$ manganese $\mathrm{Cu}=$ copper; $\mathrm{B}=$ boron.

from the genus Sedum (Durhman et al., 2007; Getter and Rowe, 2008, 2009; Monterusso et al., 2005; Nagase and Dunnett, 2010; Snodgrass, 2005; VanWoert et al., 2005; Wolf and Lundholm, 2008). As a result of the demanding and harsh conditions that the plant material is confronted with on a green roof, the plant species are limited and must comply with several criteria (Dunnett and Kingsbury, 2010); thus, both native and non-native species are usually used. However, native plants are preferred for urban green roofs as a result of their adaptation to local climatic conditions, their known growth pattern in the specific climatic region that permits the selection of non-invasive species, and their contribution to replace the lost flora in the urban environment (Bousselot et al., 2011; Dunnett and Kingsbury, 2010; Nagase and Dunnett, 2010). Native plants are also able to provide a familiar habitat for the local fauna of each region, including the attraction of pollinating insects, thus increasing the biodiversity on green roofs and enriching the existing roof vegetation with even more species of the native flora (Nagase and Dunnett, 2010).

However, the variety of native species available for selection is significantly reduced when the harsh environmental conditions and shallow substrate depth of the extensive green roofs are taken into consideration. Monterusso et al. (2005), after screening and examining the suitability of 18 native species for potential use on extensive green roofs in Michigan, concluded that only four species were able to survive on the non-irrigated extensive green roof. Consequently, the establishment of native species in extensive green roofs is appropriate under certain conditions of irrigation, substrate depth, and nutrient levels. that research must be undertaken for each region to select primarily native and secondly non-native plant species and evaluate their growth performance under the particular parameters of an extensive green roof. Dianthus fruticosus is a native plant species of the Mediterranean region; it has a bushy appearance and reaches a height of $50 \mathrm{~cm}$. Dianthus fruticosus sub. fruticosus is an endangered species found in the Cycladic Islands that grows in rock crevices at 0 to $400 \mathrm{~m}$ altitude. It has spiral stems with narrow fleshy leaves and pink flowers; it exhibits prolonged flowering from June to August. It withstands temperature extremes and drought well, whereas its strong fibrous root system provides adequate anchorage to resist wind drifts. Based on these
Based on all of these factors, it is obvious 
characteristics, D. fruticosus sub. fruticosus seems to be a promising native plant able to withstand the stresses of extensive green roofs in the Mediterranean semiarid region.

Therefore, the aims of the study were: 1) to determine the effects of substrate type and depth on growth response of $D$. fruticosus sub. fruticosus; 2) to evaluate the capacity of $D$. fruticosus sub. fruticosus to survive throughout the summer under the imposition of deficient irrigation; and 3) to determine the effects of substrate type and depth and irrigation regimens on $D$. fruticosus sub. fruticosus growth and physiological status during and after summer water stress conditions.

\section{Materials and Methods}

Experimental setup. A field study was conducted at the Laboratory of Floriculture and Landscape Architecture of the Agricultural University of Athens (lat. $37^{\circ} 59^{\prime}$, long. $23^{\circ} 42^{\prime}, 35 \mathrm{~m}$ a.s.1.) from 30 Mar. until 22 Nov. 2010. Treatments included two substrate types (soilless or soil substrate) and two substrate depths $(7.5 \mathrm{~cm}$ or $15 \mathrm{~cm})$ during the growth period (March to July) while during and after the drought stress period the two irrigation regimens $\left(15 \%\right.$ or $30 \%$ of $\left.\mathrm{E}_{\mathrm{pan}}\right)$ were considered as an additional treatment $\left(2_{\text {types }} \times 2_{\text {depths }} \times 2_{\text {irrigation }} \times 5_{\text {replications }}=40\right.$ experimental plots).

The study comprised of 40 experimental plots with internal dimensions of $60 \times 58 \mathrm{~cm}$. The plots were constructed over a uniform $20-\mathrm{cm}$ gravel layer by the use of wooden boards ( $20 \mathrm{~mm}$ wide $\times 200 \mathrm{~mm}$ in height) that prevented the sideways mechanical or hydrological continuity between adjacent plots (Fig. 1). Half of the plots had a substrate depth of $7.5 \mathrm{~cm}$ (plot volume of $0.026 \mathrm{~m}^{3}$ ), whereas the other half had a substrate depth of $15 \mathrm{~cm}$ (plot volume of $0.052 \mathrm{~m}^{3}$ ). Within each plot $\left(0.35 \mathrm{~m}^{2}\right)$, a simulation of a green roof system was constructed with the use of the appropriate layers (Fig. 1). The waterproofing protection layer, a 3-mm-thick synthetic cloth made of recycled polyester fibers and weighing $0.32 \mathrm{~kg} \cdot \mathrm{m}^{-2}$ (TSM32; Zinco, Egreen, Athens, Greece), was placed over the gravel. In actual green roof construction, the protection layer is used to protect the waterproofing membrane against mechanical damage while at the same time acts as a water reservoir by retaining $3 \mathrm{~L} \cdot \mathrm{m}^{-2}$ of water based on the manufacturer data sheet. A draining geocomposite with a $25-\mathrm{mm}$ high core and a weight of $1.5 \mathrm{~kg} \cdot \mathrm{m}^{-2}$ (FD25; Zinco) was placed over the protection cloth. The core consisted of recycled polyethylene and had the capacity to store $3 \mathrm{~L} \cdot \mathrm{m}^{-2}$ serving as an additional water storage tank based on the manufacturer data sheet. The geocomposite was covered by a non-woven geotextile (SF; Zinco) made of heat-bonded polypropylene, which was $600 \mu \mathrm{m}$ in thickness and $100 \mathrm{~g} \cdot \mathrm{m}^{-2}$ in mass, had an aperture opening size $\mathrm{O}_{90}$ of $95 \mu \mathrm{m}$, and a permeability of $0.07 \mathrm{~m} \cdot \mathrm{sec}^{-1}$. The geotextile was stapled to the boards at the sides of each experimental plot to prevent sideways movement of substrate particles to-
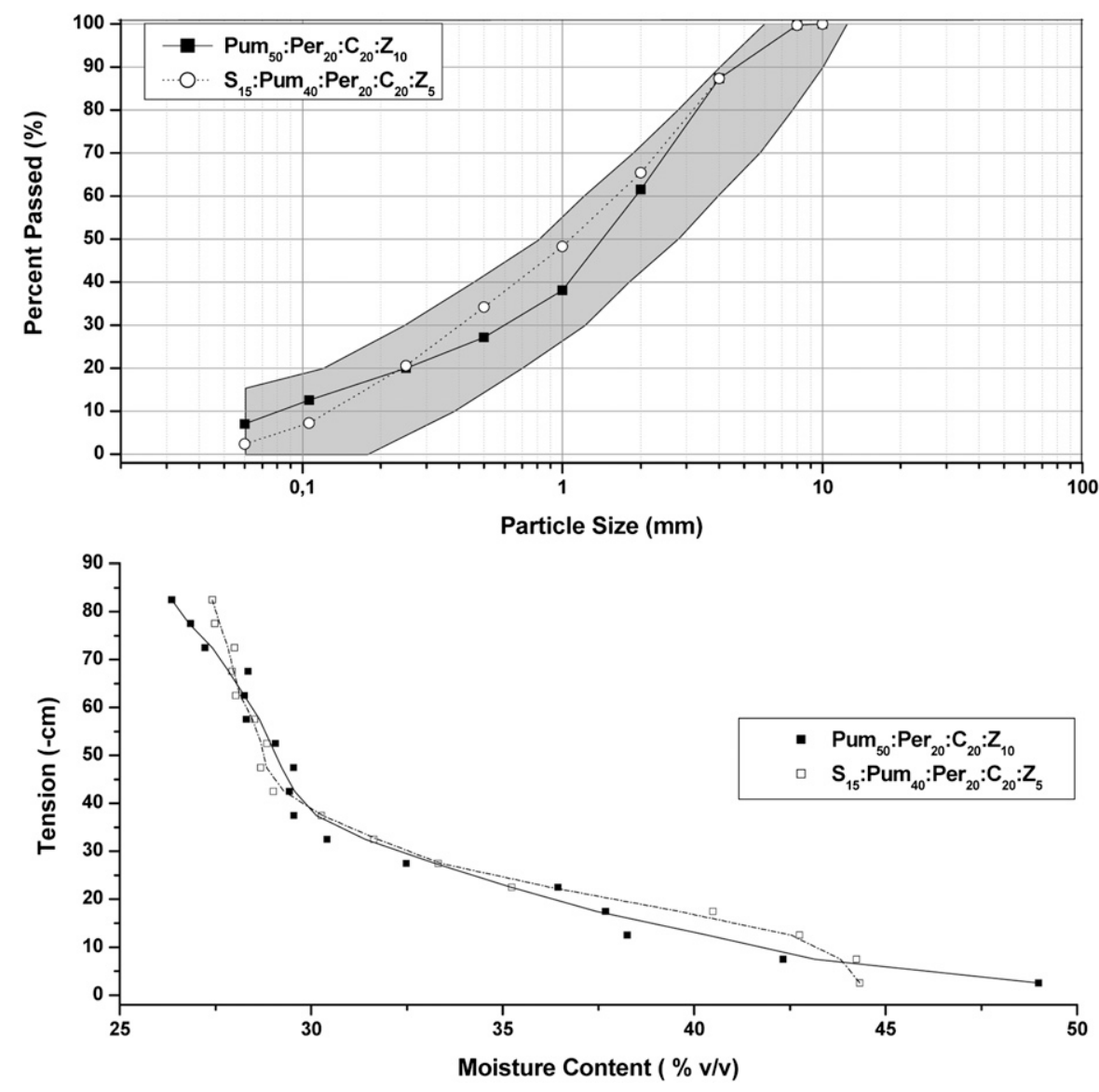

Fig. 2. (A) Particle size distribution of the two substrates $\left(\operatorname{Pum}_{50}: \operatorname{Per}_{20}: \mathrm{C}_{20}: Z_{10}\right.$ or $\mathrm{S}_{15}: \operatorname{Pum}_{40}: \operatorname{Per}_{20}: \mathrm{C}_{20}: Z_{5}$, in which $\mathrm{S}=$ sandy loam soil; $\mathrm{Pum}=$ pumice; $\mathrm{Per}=$ perlite; $\mathrm{C}=$ compost; and $\mathrm{Z}=$ zeolite). The gray area represents the specified particle size range by FLL (2002). (B) The water characteristic curves of the substrates.

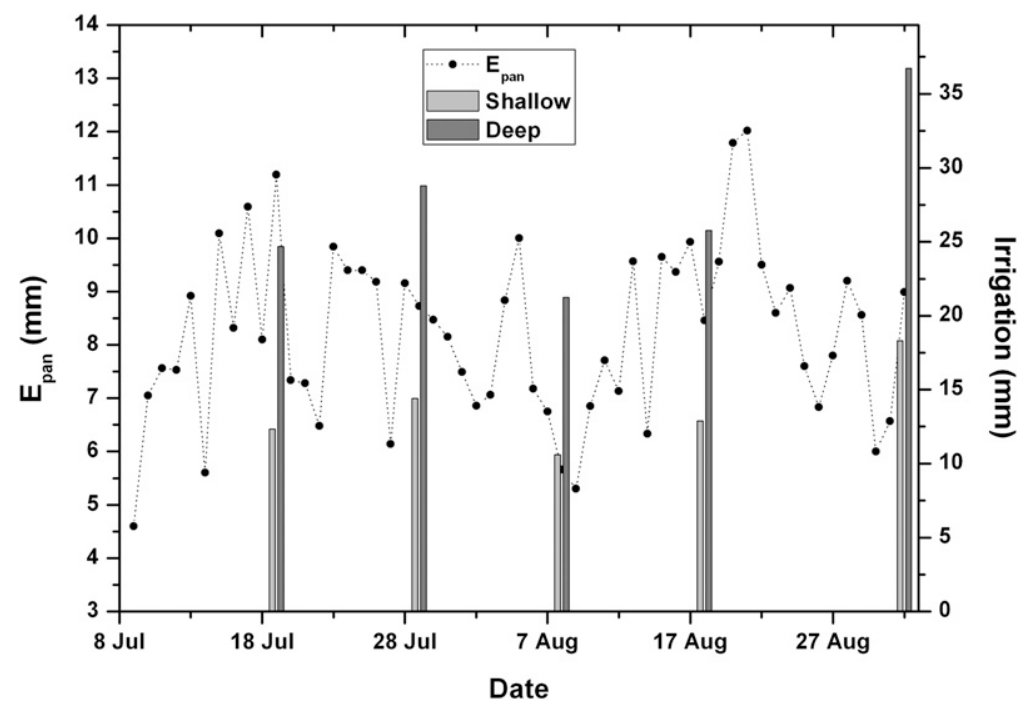

Fig. 3. Pan evaporation ( $\left.\mathrm{E}_{\mathrm{pan}}, \mathrm{mm}\right)$ and irrigation $(\mathrm{mm})$ during the drought period (7 July to 11 Sept. 2010).

ward the geocomposite drainage layer. The geotextiles were cut on all sides at a depth of 50 to $60 \mathrm{~mm}$ below the final substrate surface to interrupt the continuation of geotextile from the drainage layers toward the ambient environment and to minimize any potential wicking of water toward the atmosphere.

The geotextile was covered with two different substrates. Substrates were selected based on their compliance with FLL requirements. The FLL guidelines permit the use of extensive green roof substrates with a particle size less than $0.063 \mathrm{~mm}$ (silt and clay) not exceeding $15 \%$ by weight. However, there is an augmenting trend in the markets stating that extensive green roof substrates should be free of soil. In contrast, there is the argument that soil could act as a bridging factor between 
substrate particles that would increase waterholding capacity at low tensions, thus improving plant growth in semiarid regions. Based on the mentioned arguments, the selected substrates for the study included one soilless substrate and another with the addition of $15 \%$ sandy loam soil. All substrate components were locally available in an effort to reduce the cost and provide job opportunities for the local markets.

The soilless substrate contained pumice (Pum), perlite (Per), compost from straw, sawdust, yard waste (grass clippings and wood chips) and dairy cow, horse, and chicken manure $(\mathrm{C})$, and clinoptinolite zeolite $(\mathrm{Z})$ in a volumetric proportion of 50:20:20:10, respectively $\left(\operatorname{Pum}_{50}: \operatorname{Per}_{20}: \mathrm{C}_{20}: \mathrm{Z}_{10}\right.$, referred as soilless substrate). The second substrate included all the previous materials with the addition of $15 \% \mathrm{v} / \mathrm{v}$ sandy loam soil $(\mathrm{S})$ in a volumetric proportion of 15:40:20:20:5, respectively $\left(\mathrm{S}_{15}: \operatorname{Pum}_{40}: \operatorname{Per}_{20}: \mathrm{C}_{20}: \mathrm{Z}_{5}\right.$, referred to as soil substrate). Perlite was used as a result of its good particle size distribution, its adequate water-holding capacity $(31 \% \mathrm{v} / \mathrm{v}$ at saturation), and its reduced weight $\left(61 \mathrm{~kg} \cdot \mathrm{m}^{-3}\right)$. Hitchmough (1994) reported that perlite should be avoided in green roofs as a result of its fragile nature that alters particle size. The alteration of the particle size is presumably caused by the freeze and thawing cycles. However, in southern Mediterranean regions, freezing occurs very rarely and therefore perlite can be a choice. Clinoptinolite zeolite was used to increase the nutrient retention capacity of the substrate because this type of zeolite has the capacity to absorb and retain $\mathrm{NH}_{4}^{+}$and $\mathrm{K}^{+}$ cations in the microtunneling structure, which are then provided to the plants in a slow-release mode of action (Huang and Petrovic, 1994).

The sandy loam soil had $77.0 \%$ sand, $7.8 \%$ silt, $15.2 \%$ clay, and $0.703 \%(\mathrm{w} / \mathrm{w})$ organic matter; a pH of 8.63; and an EC of 80 $\mu \mathrm{S} \cdot \mathrm{cm}^{-1}$. Particle size distribution was 0.05 to $8 \mathrm{~mm}$ for pumice (LAVA; Mineral \& Quarry A.D., Athens, Greece), 0.8 to $2.5 \mathrm{~mm}$ for zeolite (S \& B Industrial Minerals A.D., Athens, Greece), and 1 to $5 \mathrm{~mm}$ for perlite (Perloflor; ISOCON A.D., Athens, Greece). The compost was provided by L. Kambanis S.A. (Spata, Greece), and its chemical and nutritional characteristics are listed in Table 1. The substrates were formulated by mixing the ingredients uniformly with a concrete mixer and were sufficiently compressed after their placement into the experimental plots. The filled plots were then left to settle further by natural rainfall for 2 months.

On 30 Mar. 2010, plants of the native species D. fruticosus sub. fruticosus (Caryophyllaceae) were transplanted outdoors. Four plants were transplanted in each experimental plot for a total of 160 plants ( 40 plots $\times$ four plants $/$ plot $=160$ plants). The planting distance was $15 \mathrm{~cm}$ from the edge of the plots and $30 \mathrm{~cm}$ between the plants. The plants were propagated from seeds collected from a single plant of the wild of Milos Island, Greece. Seeds were placed in palettes $(50 \times 50 \times 50 \mathrm{~mm})$ in a substrate made of equal volumes of peat and perlite (Dianthos Nurseries, Milos, Greece).
On 22 Apr. 2010, pinching was applied at a height of $15 \mathrm{~cm}$ to initiate the study with uniform plant height. Plants were irrigated every 3 d from transplanting until 8 July 2010 , when water stress treatments were initiated. In addition, plants were fertilized once on

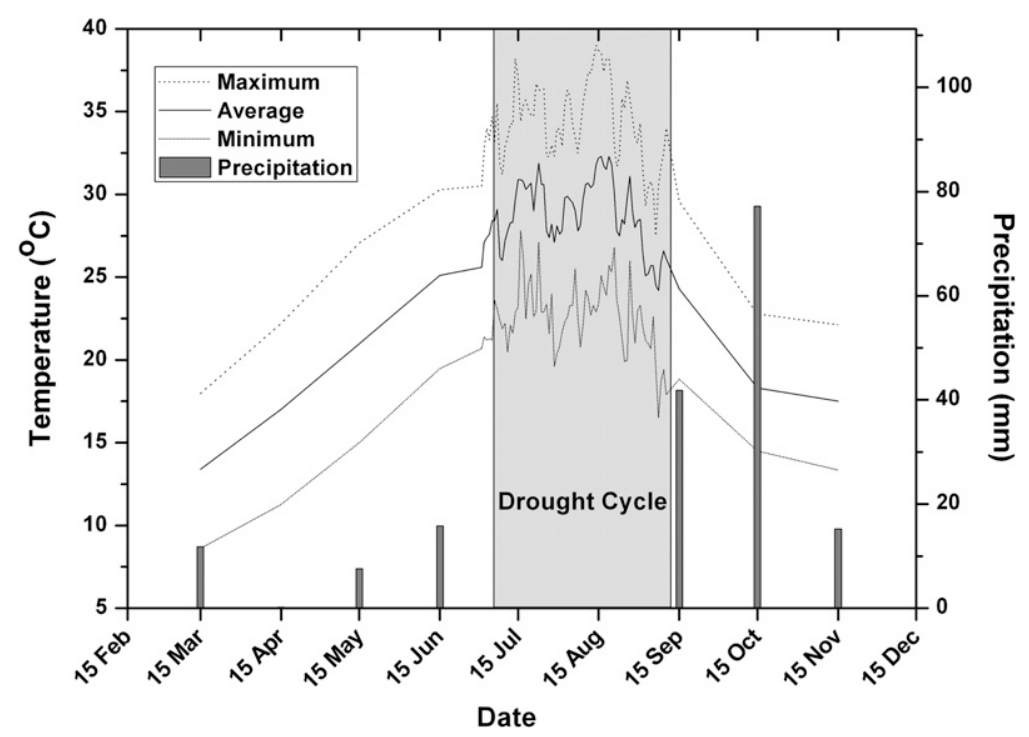

Fig. 4. Monthly precipitation and maximum, minimum, and average air temperature for the establishment period. Daily maximum, minimum, and average air temperature during the drought cycle (gray area). Data were provided by the Laboratory of General and Agricultural Meteorology at the Agricultural University of Athens.
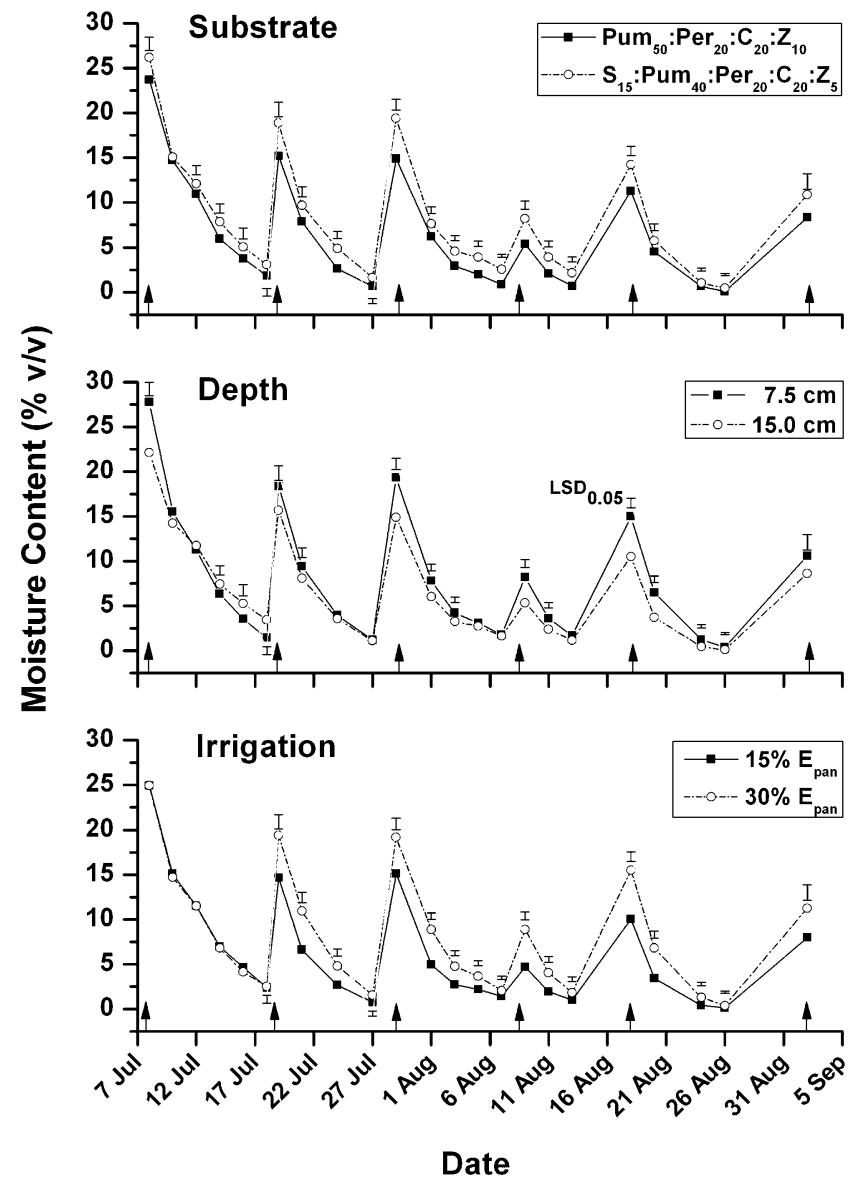

Fig. 5. Effects of substrate type $\left(\operatorname{Pum}_{50}: \operatorname{Per}_{20}: \mathrm{C}_{20}: Z_{10}\right.$ or $\mathrm{S}_{15}: \mathrm{Pum}_{40}: \operatorname{Per}_{20}: \mathrm{C}_{20}: \mathrm{Z}_{5}$, in which $\mathrm{S}=$ sandy loam soil; $P$ Pum $=$ pumice; $P$ er = perlite; $C=$ compost; and $Z=$ zeolite $)$, substrate depth $(7.5 \mathrm{~cm}$ or $15 \mathrm{~cm})$, and irrigation regimens $\left(15 \%\right.$ or $\left.30 \% \mathrm{E}_{\mathrm{pan}}\right)$ on substrate moisture fluctuation during the water stress period. Values are the means of five replications. Bars represents Fisher's least significant difference (LSD) at $P<0.05$. Arrows indicate the application of irrigation during the water stress period. 
19 May 2010 with a $16-7-15(+2 \mathrm{Mg}+9 \mathrm{~S})$ slow-release fertilizer [Floranid; COMPO HELLAS S.A., Athens, Greece; $2.1 \mathrm{NO}_{3}{ }^{-}-\mathrm{N}$, $7.9 \mathrm{NH}_{4}^{+}-\mathrm{N}, 6 \mathrm{~N}^{\prime}$-(2-methylpropyliden)bis-urea, 3.1 phosphorus, 12.5 potassium, 1.2 magnesium, 3.6 sulfur] at a rate of $6 \mathrm{~g} \cdot \mathrm{m}^{-2}$.

Substrate properties and moisture characteristic curves. Substrate granulometry was determined with the use of a series of sieves of varying screen sizes vibrated on a mechanical shaker (Vibratory Sieve Shaker AS 200 basic; Retsch Ltd., Haan, Germany). The granulometry of each substrate was plotted on a logarithmic plot to investigate the substrates' compliance with corresponding FLL (2002) specifications (Fig. 2A).

To determine the water content properties of the substrates (Fig. 2B), a soil characteristic curve was determined as described by Nektarios et al. (2011). Substrate weight was determined at both saturation and field capacity. Substrates were placed in lysimeters $45 \mathrm{~cm}$ in height and $30.5 \mathrm{~cm}$ I.D. Lysimeters were filled with the appropriate substrate mix and then pressed to 105 bars using a pressure device. The lysimeters were then filled slowly with water from the bottom using the peristaltic pump. When the lysimeters were filled with water, the saturated weight was determined using an "S type" load cell (LC101; Omega Engineering Limited, Manchester, U.K.) connected to a digital indicator (DP41-S; Omega Engineering Limited). Lysimeters were then left to drain slowly for $24 \mathrm{~h}$ while the tops were covered with plastic liners to prevent evaporation. The weight of each substrate at field capacity was determined after draining for $24 \mathrm{~h}$, again using the load cell.

Irrigation scheduling during drought stress. The amount of irrigation was calculated based on cumulative $\mathrm{E}_{\mathrm{pan}}$, which was calculated as the average from three different evaporation lysimeters placed at different locations in the experimental field. The amount of irrigation was calculated either as $15 \%$ (low irrigation treatment) or 30\% (high) of the cumulative $\mathrm{E}_{\mathrm{pan}}$ that was determined between consecutive irrigation events (Fig. 3). In several horticultural research eras, $\mathrm{E}_{\text {pan }}$ has been used as a standard irrigation norm (Bastug et al., 2006; Correia and MartinsLoução, 1995; Qian and Engelke, 1999) to determine the water requirements of a crop. Because the crop coefficient for D. fruticosus sub. fruticosus has not been determined, the selection of the irrigation treatments was decided based on the knowledge that droughttolerant warm-season turfgrasses have an average water requirement of $\approx 60 \%$ of $\mathrm{E}_{\text {pan }}$ (Carrow, 1995; Meyer and Gibeault, 1986). From preliminary studies, D. fruticosus sub. fruticosus exhibited increased drought tolerance and therefore it was decided that half of the warm-season turfgrasses water requirements $\left(30 \% \mathrm{E}_{\mathrm{pan}}\right)$ could serve as the high irrigation regimen, whereas its half $\left(15 \% \mathrm{E}_{\mathrm{pan}}\right)$ could serve as the low irrigation regimen.

During drought stress, the whole plot was hand-irrigated with a hose equipped with a flow meter having an accuracy of 0.1 L (Wohnungswasserzähler Typ ETR;
Rossweiner Armaturen \& Messgeräte $\mathrm{GmbH}$ \& Co. oHG, Rosswein, Germany). All plots received the same amount of irrigation depending on their treatment (low or high irrigation) at $\approx 10$-d intervals (Fig. 3 ) because from preliminary trials, it was determined that $D$. fruticosus sub. fruticosus became chlorotic after $\approx 10$ to $15 \mathrm{~d}$ of drought and from then on it was difficult to recover.

Substrate measurements. During the drought stress period, substrate moisture $(\% \mathrm{v} / \mathrm{v})$ was determined approximately every $2 \mathrm{~d}$ with the use of a handheld TDR moisture meter ( $\mathrm{HH} 2$; Delta-T Devise, Cambridge, U.K.) that was used in conjunction with a sensor inserted at the surface that measured $65 \mathrm{~mm}$ in depth and $45 \mathrm{~mm}$ in width (WET sensor; Delta-T Devise). At least three measurements were taken from each experimental plot and their average was reported as its moisture content.

Biometric and dry weight measurements. During and after the drought stress period, the
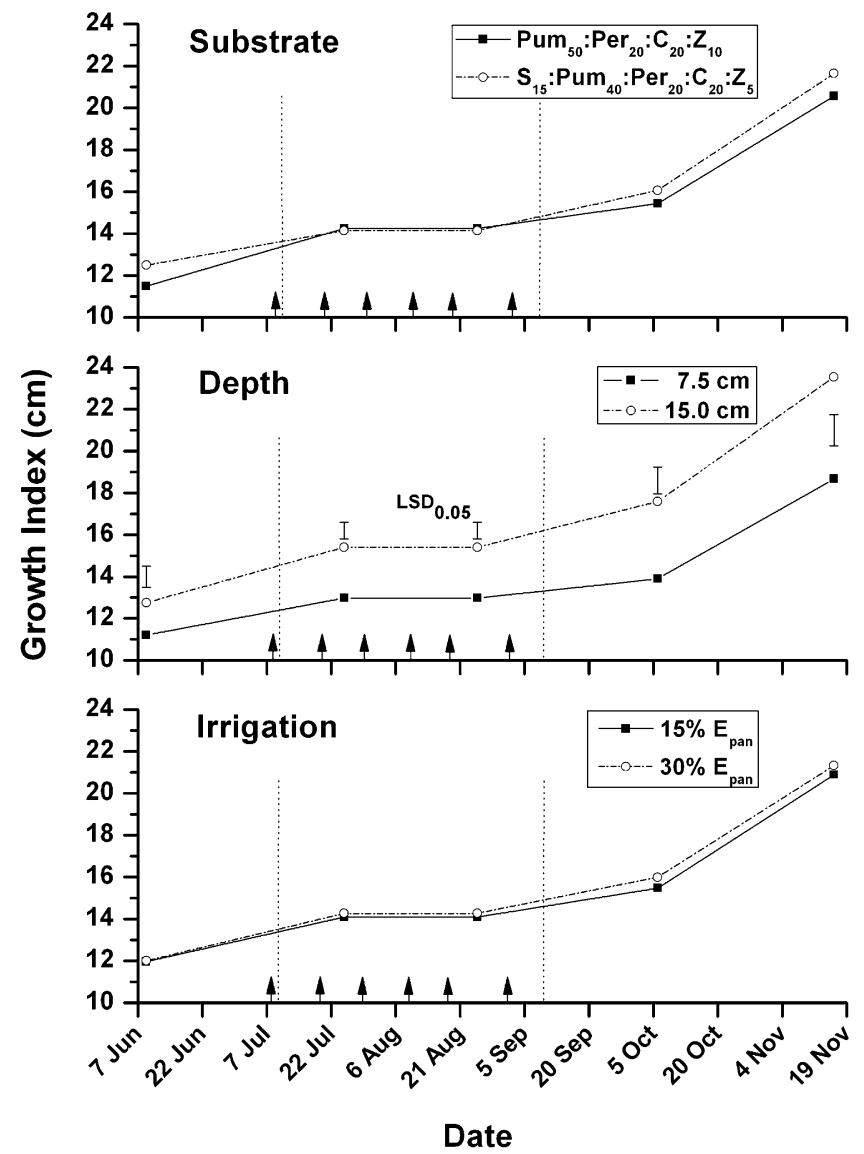

Fig. 6. Effects of substrate type $\left(\operatorname{Pum}_{50}: \operatorname{Per}_{20}: \mathrm{C}_{20}: \mathrm{Z}_{10}\right.$ or $\mathrm{S}_{15}: \mathrm{Pum}_{40}: \operatorname{Per}_{20}: \mathrm{C}_{20}: \mathrm{Z}_{5}$, in which $\mathrm{S}=$ sandy loam soil; Pum = pumice; $P$ er $=$ perlite; $C=$ compost; and $Z=$ zeolite $)$, substrate depth $(7.5 \mathrm{~cm}$ or $15 \mathrm{~cm})$, and irrigation regimens $\left(15 \%\right.$ or $\left.30 \% \mathrm{E}_{\text {pan }}\right)$ on the growth index (GI) of D. fruticosus sub. fruticosus. Values are the means of five replications. Bars represent Fisher's least significant difference (LSD) at $P<0.05$. Arrows indicate the application of irrigation during the water stress period. Dotted lines indicate the initiation and the end of the water stress period, which coincided with the first rainfall event after the summer.

Table 2. Physical, chemical, and nutritional characteristics of the substrates $\operatorname{Pum}_{50}: \operatorname{Per}_{20}: \mathrm{C}_{20}: Z_{10}$ and $\mathrm{S}_{15}:$ Pum $_{40}:$ Per $_{20}: \mathrm{C}_{20}: Z_{5}$ at the initiation of the study.

\begin{tabular}{lcc}
\hline & \multicolumn{2}{c}{ Substrate } \\
\cline { 2 - 3 } & Pum $_{50}:$ Per $_{20}: \mathrm{C}_{20}: \mathrm{Z}_{10}$ & $\mathrm{~S}_{15}:$ Pum $_{40}:$ Per $_{20}: \mathrm{C}_{20}: \mathrm{Z}_{5}$ \\
\hline Bulk density at saturation $\left(\mathrm{kg} \cdot \mathrm{m}^{-3}\right)$ & 1,276 & 1,255 \\
Dry bulk density $\pm \mathrm{SE}\left(\mathrm{kg} \cdot \mathrm{m}^{-3}\right)$ & $787 \pm 23$ & $769 \pm 24$ \\
Total porosity $(\%)$ & 49.0 & 44.3 \\
Easily available water $(\%)$ & 11.0 & 14.7 \\
Organic matter $(\%, \mathrm{w} / \mathrm{w})$ & 4.29 & 5.76 \\
Total N $(\%)$ & 0.180 & 0.240 \\
Extractable P $\left(\mathrm{mg} \cdot \mathrm{kg}^{-1}\right)$ & 116.6 & 125.1 \\
Exchangeable K $\left(\mathrm{mg} \cdot \mathrm{kg}^{-1}\right)$ & 1,362 & 1,121 \\
Exchangeable Ca $\left(\mathrm{mg} \cdot \mathrm{kg}^{-1}\right)$ & 1,978 & 2,467 \\
Exchangeable $\mathrm{Mg}\left(\mathrm{mg} \cdot \mathrm{kg}^{-1}\right)$ & 275 & 550 \\
Exchangeable Na $\left(\mathrm{mg} \cdot \mathrm{kg}^{-1}\right)$ & 700 & 608 \\
$\mathrm{pH} \pm \mathrm{SE}$ & $7.73 \pm 0.02$ & $7.89 \pm 0.00$ \\
EC $\pm \mathrm{SE}\left(\mu \mathrm{S} \cdot \mathrm{cm}^{-1}\right)$ & $488 \pm 17.5$ & $711.3 \pm 12.0$ \\
\hline
\end{tabular}

$\mathrm{S}=$ sandy loam soil; $\mathrm{Pum}=$ pumice $; \mathrm{Per}=$ perlite $\mathrm{C}=$ compost $\mathrm{Z}=$ zeolite $; \mathrm{N}=$ nitrogen $; \mathrm{P}=$ phosphorus; $\mathrm{K}=$ potassium; $\mathrm{Ca}=$ calcium $; \mathrm{Mg}$ = magnesium; $\mathrm{Na}=$ sodium; $\mathrm{EC}=$ electrical conductivity. 
GI of the plants was determined by measuring the longest dimension of the plant, its perpendicular size, and its height. Then GI was determined as:

$$
G . I .=\frac{L+W+H}{3}
$$

where $L=$ the biggest length of the plant foliage $(\mathrm{cm}), W=$ the length of the foliage at a perpendicular dimension of the $\mathrm{L}$ measurement $(\mathrm{cm})$, and $H=$ height of the plant $(\mathrm{cm})$ (Monterusso et al., 2005; Ruter, 1996). Flowering was extremely limited (only four plants flowered in mid-July) and therefore flowering measurements are not reported.

At the end of the drought stress period (8 Sept. 2010), the fresh and dry weights were determined through destructive sampling of three plants per treatment. Plants were removed from the experimental plots, and the aerial parts were separated from the root systems. In addition, the substrate was removed with the use of a vacuum cleaner and was then screened to obtain all root parts. The roots were carefully separated from the substrate by rinsing with water. The fresh weight of the aerial plant portion was determined by weighing, and then all plant parts were placed in a drying oven at $70{ }^{\circ} \mathrm{C}$ for $4 \mathrm{~d}$ to determine leaf and stem dry weights.

SPAD and chlorophyll. Leaf tissue chlorophyll $_{\mathrm{a}+\mathrm{b}}$ and carotenoid contents were determined at weekly intervals during the imposition of drought stress and at approximately monthly intervals thereafter. Simultaneously, chlorophyll measurements were obtained using a SPAD-502 Chlorophyll meter (Konica Minolta, Japan). For chlorophyll measurements, a mass of $0.5 \mathrm{~g}$ of randomly collected young but fully developed leaves was ground with $80 \%$ acetone and filtered through 1001 Whatman filter papers in $50-\mathrm{mL}$ volumetric flasks. Extraction processes were performed in the dark to avoid changes in chlorophyll content. Chlorophyll determination was performed on the supernatant with a spectrophotometer (ultravioletVisible Helios Gamma \& Delta; Spectronic Unicam, Mercers Row, Cambridge, U.K.) at three different wavelengths $(663 \mathrm{~nm}$ and 645 $\mathrm{nm}$ for chlorophyll and $470 \mathrm{~nm}$ for carotenoids). Chlorophylls a and b were determined according to Arnon's (1949) Eqs. [1] and [2] as follows:

$C h l_{a}=\left(12.7 \times \mathrm{D}_{663}-2.69 \times \mathrm{D}_{645}\right) \times \frac{\mathrm{V}}{1000} \times \mathrm{w}$

$C h l_{b}=\left(22.9 \times \mathrm{D}_{645}-4.68 \times \mathrm{D}_{663}\right) \times \frac{\mathrm{V}}{1000} \times \mathrm{w}$

$$
C h l_{a+b}=C h l_{a}+C h l_{b}
$$

Carotenoids $=\frac{\left(1000 \times \mathrm{D}_{470}-1.82 \times \mathrm{D}_{663}-85.02 \times \mathrm{D}_{645}\right)}{198 \times \mathrm{D}_{663}}$

where $D_{663}, \mathrm{D}_{645}, \mathrm{D}_{470}=\operatorname{density}\left(\mathrm{mg} \cdot \mathrm{L}^{-1}\right)$ values at the respective wavelengths of 663 ,
645 , and $470 \mathrm{~nm} ; \mathrm{V}=$ volume of the extract; and $\mathrm{w}=$ weight of the leaf samples.

Meteorological data. The ambient maximum, minimum, and average temperature and precipitation (Fig. 4) were recorded by the Laboratory of General and Agricultural
Meteorology at the Agricultural University of Athens. It is stressed that during the drought period, no rainfall occurred.

Statistical analysis. The experimental design was a multifactorial with three factors under consideration: two substrates (with or

Table 3. Effects of substrate type $\left(\operatorname{Pum}_{50}: \operatorname{Per}_{20}: \mathrm{C}_{20}: \mathrm{Z}_{10}\right.$ or $\mathrm{S}_{15}: \operatorname{Pum}_{40}: \operatorname{Per}_{20}: \mathrm{C}_{20}: \mathrm{Z}_{5}$ in which $\mathrm{S}=$ sandy loam soil; $\mathrm{Pum}=$ pumice; $\mathrm{Per}=$ perlite $\mathrm{C}=$ compost; and $\mathrm{Z}=$ zeolite $)$, substrate depth $(7.5 \mathrm{~cm}$ or $15 \mathrm{~cm})$

\begin{tabular}{|c|c|c|c|c|}
\hline & Leaf fresh wt & Leaf dry wt & Stem dry wt & Root dry wt \\
\hline & \multicolumn{4}{|c|}{ (g/plant) } \\
\hline \multicolumn{5}{|l|}{ Substrate type } \\
\hline$\left(\right.$ Pum $_{50}:$ Per $\left._{20}: \mathrm{C}_{20}: \mathrm{Z}_{10}\right)$ & $55.77( \pm 10.52)$ & $20.95( \pm 2.81)$ & $6.51( \pm 1.11)$ & $10.64( \pm 3.31)$ \\
\hline$\left(\mathrm{S}_{15}:\right.$ Pum $\left._{40}: \operatorname{Per}_{20}: \mathrm{C}_{20}: Z_{5}\right)$ & $59.22( \pm 14.64)$ & $20.62( \pm 4.54)$ & $5.91( \pm 1.13)$ & $7.94( \pm 1.71)$ \\
\hline Significance & NS & NS & NS & NS \\
\hline \multicolumn{5}{|l|}{ Substrate depth } \\
\hline $7.5 \mathrm{~cm}$ & $47.36( \pm 8.56)$ & $18.07( \pm 2.98)$ & $5.55( \pm 1.23)$ & $8.07( \pm 2.62)$ \\
\hline $15 \mathrm{~cm}$ & $67.63( \pm 13.39)$ & $23.50( \pm 3.78)$ & $6.86( \pm 0.88)$ & $10.51( \pm 2.69)$ \\
\hline Significance & $*$ & $*$ & NS & NS \\
\hline \multicolumn{5}{|l|}{ Irrigation regimens } \\
\hline $15 \% \mathrm{E}_{\mathrm{pan}}$ & $52.79( \pm 12.98)$ & $19.85( \pm 3.63)$ & $6.14( \pm 1.06)$ & $9.75( \pm 2.75)$ \\
\hline $30 \% \mathrm{E}_{\text {pan }}$ & $62.20( \pm 11.95)$ & $21.72( \pm 3.84)$ & $6.281( \pm 1.21)$ & $8.83( \pm 2.73)$ \\
\hline Significance & NS & NS & NS & NS \\
\hline Least significant difference & 18.34 & 5.39 & 1.68 & 4.26 \\
\hline
\end{tabular}
and amount of irrigation $\left(15 \%\right.$ or $\left.30 \% \mathrm{E}_{\text {pan }}\right)$ on Dianthus fruticosus sub. fruticosus dry weight. ${ }^{\mathrm{z}}$

${ }^{\mathrm{z}}$ Values are the means of three replications $( \pm \mathrm{SE})$.

* Significant at $P<0.05$.

NS, Non-significant at $P<0.05$.
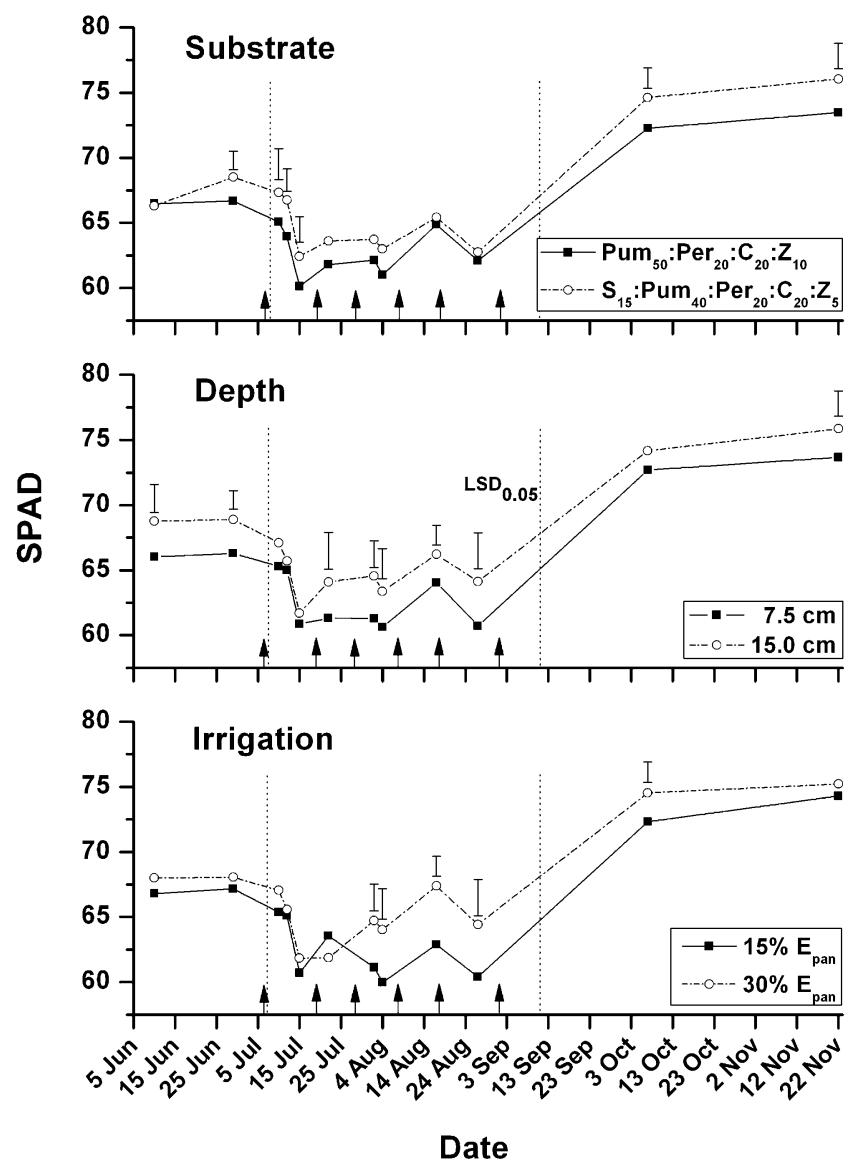

Fig. 7. Effects of substrate type (Pum $50: P_{20}: C_{20}: Z_{10}$ or $S_{15}: P_{40}: P_{20}: C_{20}: Z_{5}$, in which $S=$ sandy loam soil; Pum = pumice; $P$ er = perlite $C \mathrm{C}=$ compost; and $\mathrm{Z}=$ zeolite $)$, substrate depth $(7.5 \mathrm{~cm}$ or $15 \mathrm{~cm})$, and irrigation regimens $\left(15 \%\right.$ or $\left.30 \% \mathrm{E}_{\mathrm{pan}}\right)$ on $D$. fruticosus sub. fruticosus SPAD measurements. Values are the means of five replications. Bars represent Fisher's least significant difference (LSD) at $P<0.05$. Arrows indicate the application of irrigation during the water stress period. Dotted lines indicate the initiation and end of the water stress period, which coincided with the first rainfall event after the summer. 
without soil), two substrate depths $(7.5 \mathrm{~cm}$ or $15 \mathrm{~cm}$ ), and two irrigation regimens during the water stress period ( $15 \%$ or $30 \%$ of $\left.E_{\text {pan }}\right)$ (two substrate types $\times$ two substrate depths $\times$ two irrigation regimens $\times$ five replications $=$ 40 plots).

The experimental plots were arranged following a completely randomized design, and analysis of variance was performed on the collected data using JMP $^{\circledR}$ Version 8 statistical software (SAS Institute Inc., Cary, $\mathrm{NC}$ ). Because the main research interest was on treatment effects on D. fruticosus sub. fruticosus growth within each separate sampling date, statistical analysis was performed using multivariate analysis of variance of $\mathrm{JMP}^{\circledR}$ Version 8 statistical software comparing treatment effects within each separate sampling date. Treatment means for all statistical analyses were compared using the Fisher's protected least significant difference at a probability level of $P<0.05$. There were minimal interactions between treatments, and therefore, the results are presented as a multifactorial analysis.

\section{Results and Discussion}

Substrate properties and moisture characteristic curves. In both substrates, the particle size distribution fell within the FLL specifications (FLL, 2002) for multiple-layered extensive green roof systems (Fig. 2A). Soil substrate was coarser in the 2 to $0.5 \mathrm{~mm}$ but finer in the 0.105 to $0.06 \mathrm{~mm}$ fraction compared with substrate $\operatorname{Pum}_{50}: \operatorname{Per}_{20}: \mathrm{C}_{20}: Z_{10}$. These differences were caused by the presence of the soil fraction. The similarity in particle size distribution between the two substrates resulted in water characteristic curves that were also similar for the $30-$ to $65-\mathrm{cm}$ tensions. However, the soilless substrate retained more water at low tensions ( 0 to $20 \mathrm{~cm}$; Fig. 2B). In contrast, the soil substrate retained more water in increased tensions ( $65 \mathrm{~cm}$ or greater) than the soilless substrate as a result of the presence of soil in the mix, which was indicative of a different pore size distribution that enabled water retention in higher tensions (Aggelides and Londra, 2000). Both substrates had reduced dry and saturated bulk density, but the soil substrate had increased easily available water compared with the soilless substrate $(14.7 \%$ and $11.0 \%$, respectively).

Substrate measurements. During the imposition of drought stress, the moisture content of the substrate fluctuated between consecutive irrigation events (Fig. 5). The soil substrate retained more water than the soilless substrate at all sampling dates, which was expected based on their water characteristic curves, especially in increased tensions (Fig. 2B). The water moisture of the profile was increased in the shallow substrates $(7.5 \mathrm{~cm})$ compared with the deep substrates $(15.0 \mathrm{~cm})$, whereas the rate of water loss was faster in the shallow substrates as indicated by the slope of the drying curves (Fig. 5). The faster drying of the shallow profiles resulted in similar moisture contents between the two depths before the application of the following irrigation event. The moisture measurements depicted the moisture content of the substrate surface $(6.5 \mathrm{~cm})$ and not of the whole profile; thus, the moisture of the deep substrates was expected to be higher than that of the shallow ones. In the case of the shallow substrates, the proximity of the water to the surface of the substrates resulted in faster evaporation that was depicted by the faster rate of moisture loss from the shallow substrates (Fig. 5). Substrate moisture also increased in the high irrigation $\left(30 \% \mathrm{E}_{\mathrm{pan}}\right)$ compared with the low irrigation regimen $\left(15 \% E_{p a n}\right)$, as expected as a result of the increased water inputs.

Biometric and dry weight measurements. Deep substrates promoted the growth of $D$. fruticosus sub. fruticosus as indicated by the GI values (Fig. 6). The GI in the 15-cm depth was higher than in the $7.5-\mathrm{cm}$ depth from the early stages of establishment until the end of the study, whereas differences between the two depths remained unaltered during the drought period. In contrast, neither the substrate type nor the amount of irrigation led to differences in the GI of the plant. The influence of substrate depth has been established by other researchers as well. Durhman et al. (2007) found increased plant survival rates at $5.0-\mathrm{cm}$ and $7.5-\mathrm{cm}$ depths compared with a $2.5-\mathrm{cm}$ substrate depth, whereas Getter and Rowe (2008) investigated the effect of substrate depth on Sedum establishment on green roofs by evaluating the absolute cover and found that as the substrate depth increased from $4.0 \mathrm{~cm}$ to $7.0 \mathrm{~cm}$ and then to $10.0 \mathrm{~cm}$, absolute coverage increased for most of the species under evaluation. The same authors (Getter and Rowe, 2009) found that most Sedum species performed equally well between $7 \mathrm{~cm}$ and $10 \mathrm{~cm}$ of substrate depth, whereas increasing the depth from 4 $\mathrm{cm}$ to $7 \mathrm{~cm}$ was beneficial to plant absolute coverage in a long-term study that lasted 3 years. VanWoert et al. (2005) concluded that a substrate depth of $6.0 \mathrm{~cm}$ provided better plant growth than a depth of $2.0 \mathrm{~cm}$ as a result of better moisture retention during drought stress. Similarly Thuring et al. (2010) found that increasing substrate depth from $2.5 \mathrm{~cm}$ to $6 \mathrm{~cm}$ and then to $12 \mathrm{~cm}$ was the most beneficial green roof factor among substrate type, depth, and irrigation scheduling for plant establishment and their drought tolerance. In our case, differences in the GI resulting from substrate depth were detected from the early stages of establishment, and from then on, they increased whenever the plants were not under stress (Fig. 6), indicating that the observed 
differences were probably caused either by the higher water content of the deep substrates or by the amelioration of temperature extremes (Boivin et al., 2001) because the nutrient status was similar concerning nitrogen, phosphorus, and potassium for both substrates (Table 2).

Fresh and dry weight determination at the end of the drought stress period revealed that stem and root dry weights were similar for all treatments, but the fresh and dry weights of the leaves were higher in the $15-\mathrm{cm}$ than in the 7.5-cm deep substrate (Table 3 ). The increase was again attributed to the increased moisture of the deep substrates. Similar to our results, VanWoert et al. (2005) found increased shoot dry weight of Sedum plants as the depth of the substrate increased from $2.0 \mathrm{~cm}$ to $6.0 \mathrm{~cm}$.

SPAD and chlorophyll. The alteration of plant physiology as a reaction to the treatments was evaluated by both SPAD measurements and chlorophyll ${ }_{\mathrm{a}+\mathrm{b}}$ content. SPAD measurements (Fig. 7) seemed to be more sensitive than $\mathrm{Chl}_{\mathrm{a}+\mathrm{b}}$ (Fig. 8) and showed significant differences in all treatments. The soil substrate increased SPAD values during the samplings just before the initiation and during the first stages of drought stress as well as after the recovery of plants in October and November. However, within the drought stress period, SPAD values were similar for the two substrate types, indicating that the detected differences in water retention between the two substrates did not indicate any significant differences in the physiological status/greenness of the plants (Fig. 7). In contrast, the deep substrates continuously provided better SPAD values than the shallow substrates before, during, and after the drought period, supporting the findings concerning the improved growth (GI) of the plants in the 15-cm substrate depth (Fig. 6). This further substantiated the conclusion that the depth of the substrates seemed to be the most influential factor on $D$. fruticosus sub. fruticosus physiology when grown on green roof systems. The increased irrigation $(30 \%$ $\left.E_{p a n}\right)$ led to better SPAD measurements compared with $15 \% \mathrm{E}_{\text {pan }}$ only after drought stress was imposed for 1 month, but its impact was still detectable for 1 month after the end of the drought stress (2 Aug. until 7 Oct. 2010) (Fig. 7). During that period, the detected differences between irrigation treatments were larger than those observed between the other factors under investigation (substrate type and depth).

Differences between the three factors (substrate type and depth and irrigation regimens) varied according to drought severity. More specifically, at the initiation of the drought period (29 June until 15 July 2010), substrate type and depth were the most significant factors affecting plant growth, whereas irrigation had no effect because the plants were coming from a period of sufficient irrigation (Fig. 7). As the drought progressed, the influence of substrate type became negligible, and substrate depth became the most influential factor for plant physiological status (22 July until 27 Aug. 2010). Finally, from the middle to the end of the drought (2 Aug. until 8 Sept. 2010), the irrigation regime and, to a lesser degree, the substrate depth, with its increased moisture, were the factors that influenced plant physiology, whereas substrate type had no effect.

Chlorophyll analysis showed only minimal differences between the treatments (Fig. 8 ), indicating that SPAD should be preferred as a measurement whenever leaf morphology permits its use. Chlorophyll measurements were able to detect the general deterioration of the plant physiological status during the drought period as well as its recovery after the drought but were unable to detect differences between the treatments. Chlorophyll measurements were able to detect only two differences, whereas with SPAD, 19 differences were detected between treatments. Of the two detected chlorophyll differences between treatments, one concerned the substrate type (22 July 2010; Fig. 8) and the second indicated that the deep substrate plants had more chlorophyll $\mathrm{a}_{\mathrm{a}+\mathrm{b}}$ and retained better physiological status compared with the shallow substrates close to the end of the drought period (20 Aug. 2010). The quick decline of chlorophylls as a result of drought has also been substantiated by Durhman et al. (2006) using chlorophyll fluorescence in green roof Sedum and two non-CAM plants. They found that the chlorophyll of the nonCAM plants declined within the first $4 \mathrm{~d}$ after drought imposition.

The results obtained for carotenoids were similar to the chlorophyll measurements. More specifically, carotenoid levels decreased immediately after the initiation of drought and increased only on the first irrigation event after the initiation of drought (Fig. 9), indicating that the plants tried to recover after the first irrigation during the drought period (22 July 2010). From then on, carotenoid concentrations dropped continuously until the end of the drought period. The detected differences had exactly the same pattern as those of the chlorophylls. Carotenoids are known indicators because their concentrations decrease as soon as plants enter into a water stress period (Deo and Biswalb, 2001). In both chlorophyll and carotenoids, the drop in concentration occurred immediately after the initiation of the drought period. At the first irrigation event after drought initiation, chlorophylls retained their concentrations, whereas the

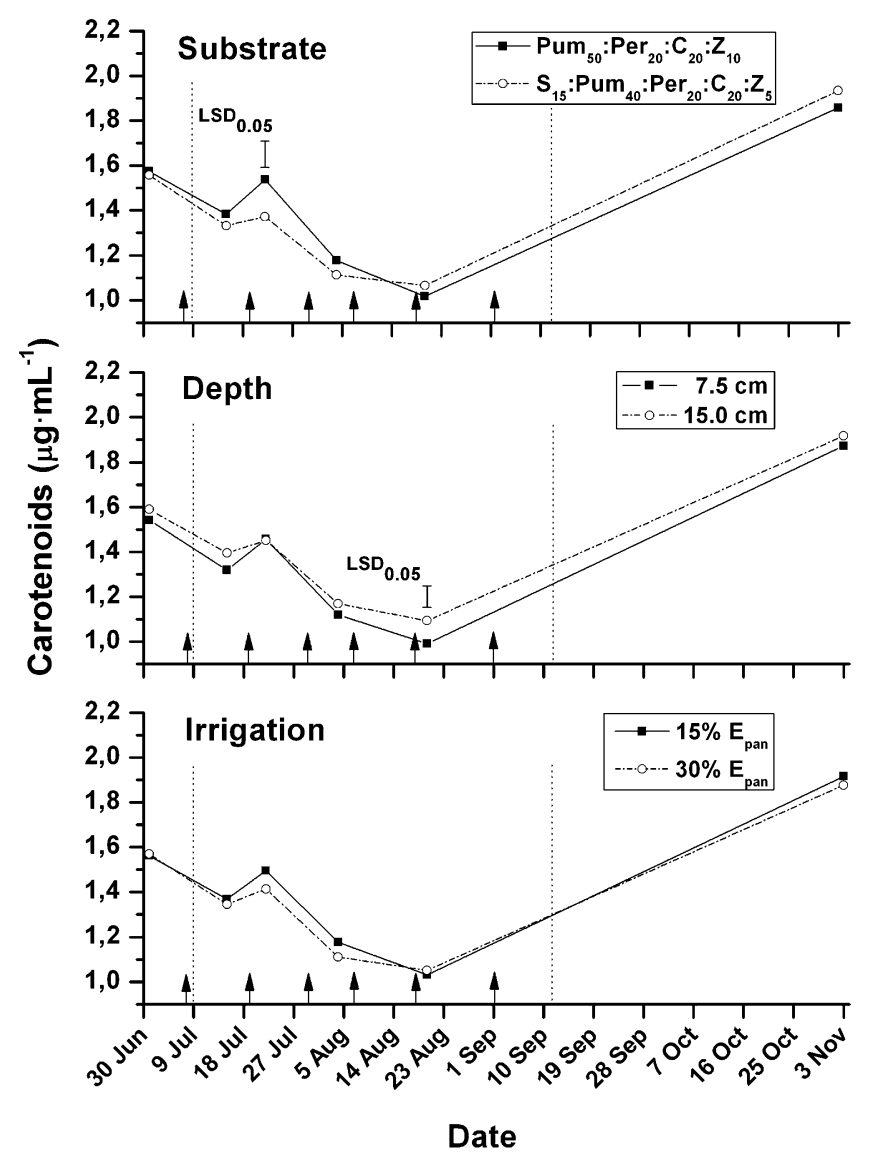

Fig. 9. Effects of substrate type $\left(\operatorname{Pum}_{50}: \operatorname{Per}_{20}: \mathrm{C}_{20}: Z_{10}\right.$ or $\mathrm{S}_{15}: \mathrm{Pum}_{40}: \mathrm{Per}_{20}: \mathrm{C}_{20}: \mathrm{Z}_{5}$, in which $\mathrm{S}=$ sandy loam soil Pum $=$ pumice; $P$ er $=$ perlite $; C=$ compost and $Z=$ zeolite $)$, substrate depth $(7.5 \mathrm{~cm}$ or $15 \mathrm{~cm})$, and irrigation regimens $\left(15 \%\right.$ or $\left.30 \% \mathrm{E}_{\mathrm{pan}}\right)$ on $D$. fruticosus sub. fruticosus carotenoids concentration $\left(\mu \mathrm{g} \cdot \mathrm{mL}^{-1}\right)$. Values are the means of five replications. Bars represent Fisher's least significant difference (LSD) at $P<0.05$. Arrows indicate the application of irrigation during the stress period. Dotted lines indicate the initiation and end of the stress period, which coincided with the first rainfall event after the summer. 
concentrations of carotenoids increased. From then on, the concentrations of both chlorophylls and carotenoids decreased until the end of the drought.

\section{Conclusions}

Based on our research, D. fruticosus sub. fruticosus is a promising endemic species with very good potential for establishment on semiarid green roofs of the Mediterranean region. The depth of the substrate was found to be the most critical factor for improving the establishment, growth, and drought tolerance of $D$. fruticosus sub. fruticosus. However, the plants were able to grow successfully in the shallow substrate depth of $7.5 \mathrm{~cm}$, even with the reduced irrigation of $15 \%$ of $\mathrm{E}_{\mathrm{pan}}$. Based on the SPAD measurements, the incorporation of the soil in the substrate provided better plant physiological status before the drought stress period but this did not affect the plant GI. Therefore, excluding soil from the substrate is not expected to either significantly reduce or hinder D. fruticosus sub. fruticosus growth.

\section{Literature Cited}

Aggelides, S.M. and P.A. Londra. 2000. Effects of compost produced from town wastes and sewage sludge on the physical properties of a loamy and a clay soil. Bioresour. Technol. 71:253-259.

Arnon, D.I. 1949. Copper enzymes in isolated chloroplasts. Polyphenoloxidase in Beta vulgaris. Plant Physiol. 24:1-15.

Bastug, R., O. Karaguzel, K. Aydinsakir, and D. Buyuktas. 2006. The effects of drip irrigation on flowering and flower quality of glasshouse gladiolus plant. Agr. Water Mgt. 81:132-144.

Beattie, D.J. and R.D. Berghage. 2004. Green roof media characteristics: The basic, p. 411-416. In: Proc. of 2nd North American Green Roof Conference: Greening Rooftops for Sustainable Communities Conference, Portland, OR, 2-4 June 2004. The Cardinal Group, Toronto, Canada.

Boivin, M., M. Lamy, A. Gosselin, and B. Dansereau. 2001. Effect of artificial substrate depth on freezing injury of six herbaceous perennials grown in a green roof system. HortTechnology 11:409-412.

Bousselot, J.M., J.E. Klett, and R.D. Koski. 2011. Moisture content of extensive green roof substrate and growth response of 15 temperate plant species during dry down. HortScience 46:518-522.
Carrow, R.N. 1995. Drought resistance aspects of turfgrasses in the southeast: ET and crop coefficients. Crop Sci. 35:1685-1690.

Correia, P.J. and M.A. Martins-Loução. 1995. Seasonal variations of leaf water potential and growth in fertigated carob-trees (Ceratonia siliqua L.). Plant Soil 172:199-206.

Deo, P.M. and B. Biswalb. 2001. Response of senescing cotyledons of clusterbean to water stress in moderate and low light: Possible photoprotective role of b-carotene. Physiol. Plant. 112:47-54.

Dunnett, N. and N. Kingsbury. 2010. Planting green roofs and living walls. 2nd Ed. Timber Press, Cambridge, UK.

Dunnett, N., A. Nagase, and A. Hallam. 2007. The dynamics of planted and colonising species on a green roof over six growing seasons 20012006: Influence of substrate depth. Urban Ecosyst. 11:373-384.

Durhman, A.K., D.B. Rowe, and C.L. Rugh. 2006 Effect of water regimen on chlorophyll fluorescence and growth of selected green roof plant taxa. HortScience 41:1623-1628.

Durhman, A.K., D.B. Rowe, and C.L. Rugh. 2007. Effect of substrate depth on initial growth, coverage, and survival of 25 succulent green roof plant taxa. HortScience 42:588-595.

FLL. 2002. Guideline for the planning, execution and upkeep of green-roof sites (English ed.). Forschungsgesellschaft Landschaftsentwicklung Landschaftsbau.

Getter, K.L. and D.B. Rowe. 2006. The role of extensive green roofs in sustainable development. HortScience 41:1276-1285.

Getter, K.L. and D.B. Rowe. 2008. Media depth influences Sedum green roof establishment. Urban Ecosyst. 11:361-372.

Getter, K.L. and D.B. Rowe. 2009. Substrate depth influences Sedum plant community on a green roof. HortScience 44:401-407.

Hitchmough, J. 1994. Urban landscape management. Incata Press, Sydney, Australia.

Huang, Z.T. and A.M. Petrovic. 1994. Clinoptilolite zeolite influence on nitrate leaching and nitrogen use efficiency in simulated sand based golf greens. J. Environ. Qual. 23:1190-1194.

Latocha, P. and A. Batorska. 2007. The influence of irrigation system on growth rate and frost resistance of chosen ground cover plants on extensive green roofs. Ann. Warsaw Univ. of Life Sc.-SGGW. Horticult. and Landsc. Architect. 28:131-137.

Meyer, J.L. and V.A. Gibeault. 1986. Turfgrass performance under reduced irrigation. Calif. Agr. 40:19-20.

Monterusso, M.A., D.B. Rowe, and C.L. Rugh. 2005. Establishment and persistence of Sedum spp. and native taxa for green roof applications. HortScience 40:391-396.

Nagase, A. and N. Dunnett. 2010. Drought tolerance in different vegetation types for extensive green roofs: Effects of watering and diversity. Landsc. Urban Plan. 97:318-327.

Nektarios, P.A., S. Kastritsis, N. Ntoulas, and P. Tsiotsiopoulou. 2011. Substrate amendment effects on potted plant production and dry weight partition of Lantana camara. HortScience 46:864-869.

Nektarios, P.A., P. Tsiotsiopoulou, and I. Chronopoulos. 2003. Soil amendments reduce roof garden weight and influence the growth rate of Lantana. HortScience 38:618-622.

Qian, Y.L. and M.C. Engelke. 1999. Performance of five turfgrasses under linear gradient irrigation. HortScience 35:893-896.

Rowe, D.B., M.A. Monterusso, and C.L. Rugh. 2006. Assessment of heat-expanded slate and fertility requirements in green roof substrates. HortTechnology 16:471-477.

Ruter, J.M. 1996. Paclobutrazol application method influences growth and flowering of 'new gold' lantana. HortTechnology 6:19-20.

Scrivens, S. 1990. Urban landscape and roof gardens, p. 131-151. In: Clouston, B. (ed.) Landscape design with plants. 2nd Ed. Butterworth-Heinemann Ltd., Oxford, U.K.

Snodgrass, E. 2005. 100 Extensive green roofs: Lessons learned, p. 209-214. In: Proc. of 3rd North American Green Roof Conference: Greening rooftops for sustainable communities Washington, DC, 4-6 May 2005. The Cardinal Group, Toronto, Canada.

Spronken-Smith, R.A. and T.R. Oke. 1998. The thermal regime of urban parks in two cities with different summer climates. Intl. J. Remote Sens. 19:2085-2104.

Takebayashi, H. and M. Moriyama. 2009. Study on the urban heat island mitigation effect achieved by converting to grass-covered parking. Sol. Energy 83:1211-1223.

Thuring, C.E., R.D. Berghage, and D.J. Bettie. 2010. Green roof plant responses to different substrate types and depths under various drought conditions. HortTechnology 20:395-401.

VanWoert, N.D., D.B. Rowe, J.A. Andresen, C.L. Rugh, and L. Xiao. 2005. Watering regime and green roof substrate design affect Sedum plant growth. HortScience 40:659-664.

Williams, N.S.G., J.P. Rayner, and K.J. Raynor. 2010 Green roofs for a wide brown land: Opportunities and barriers for rooftop greening in Australia. Urban For. Urban Green. 9:245-251.

Wolf, D. and J.T. Lundholm. 2008. Water uptake in green roof microcosms: Effects of plant species and water availability. Ecol. Eng. 3:179-186. 